\title{
ANALISIS FAKTOR - FAKTOR YANG MEMPENGARUHI RETURN SAHAM PERBANKAN GO PUBLIC DENGAN NILAI PERBANKAN SEBAGAI VARAIBEL INTERVENING Astohar $^{1}$, Yuyun Ristianawati ${ }^{2}$ atau Dewi Oktafiani ${ }^{3}$ \\ S1 Akuntansi, STIE Totalwin \\ 1astohardemak@gmail.com \\ D3 Manajemen Perusahaan, STIE Totalwin \\ 2yuyun@stietotalwin.ac.id \\ S1 Manajemen, STIE Totalwin \\ 3dewioktafiani21101999@gmail.com
}

\begin{abstract}
ABSTRAK
Return saham perbankan selama 6 tahun dari tahun 2014 sampai dengan 2019 adalah berfluktuatif. Hasil penelitian terdahulu menunjukkan terjadi gap serta adanya rekomendasi untuk membuat model penelitian factor - factor yang mempengaruhi return saham perbankan yang go public secara bertingkat (Struktural). Populasi dalam penelitian ini adalah sebanyak 43 perbankan go public. Besar sampel yang digunakan sebanyak 35 bank dengan metode pengambilan sampel menggunakan purposive sampling, sehingga jumlah observasi sebanyak 210 observasi. Alat analisis yang digunakan adalah menggunakan persamaan regresi linier berganda dan sobel test (uji mediasi). Hasil penelitian menunjukkan bahwa capital adequacy ratio (CAR), return on equity (ROE) terbukti mempunyai pengaruh positif dan signifikan terhadap price book to value $(P B V)$. Price book to value (PBV) mempunyai pengaruh positif dan signifikan terhadap return saham perbankan yang go public di Indonesia. Return on equity (ROE) secara langsung terbukti berpengaruh terhadap return saham, sedangkan capital adequacy $(C A R)$ dan loan to deposit ratio $(L D R)$ tidak terbukti berpengaruh terahdap return saham. Price to book value mampu memediasi pengaruh capital adequacy ratio $(C A R)$, return on equity (ROE) dan loan to deposit ratio $(L D R)$ terhadap return saham perbankan yang go public di Indonesia.
\end{abstract}

Kata kunci : CAR, ROE, LDR, PBV dan Return Saham.

\section{PENDAHULUAN}

Bank merupakan suatu lembaga yang bergerak di bidang keuangan dengan operasional menjual atau menjalankan jasa. Jasa kepada masyarakat salah satunya berupa pelayanan di keuangan. Pelayanan yang bagus dan paripurna ditunjukkan bagaimana kinerja perbankan terbentuk. (Purnamasari dkk, 2017). Menurut Sunaryo (2020) tuntutan dan dampak dari perkembangan perekonomian Indonesia saat ini adalah makin pentingnya dan berperannya industri bank. Perbankan menjadi sektor yang sangat penting dan diperlukan dalam mendukung seluruh kegiatan ekonomi atau kegiatan- kegiatan lainnya yang ada urusan dengan penyaluran dana di Indonesia.

Pasar modal memberikan kesempatan perusahaan untuk bersaing secara sehat dalam rangka menarik minat investor agar menanamkan modalnya diperusahaannya (Antari, dkk, 2020). Pada pasar modal ini terbentuk suatu harga saham dengan melalui hukum ekonomi yaitu dengan permintaan dan penawaran. Menurut Fahlevi et al, (2018) harga saham yang meningkat pada suatu perusahaan dapat terjadi dikarenakan adanya kenaikan permintaan saham tersebut. Dalam membeli saham atau memilih suatu 
investasi, seorang investor harus melakukan penilaian terlebih dahulu terhadap perusahaan yang akan dituju.

Menurut Sunaryo (2020) perbankan dalam perkembangan juga membutuhkan dana untuk berkembang, salah satu cara adalah dengan go public. Perbankan adalah salah satu penopang perekonomian di Indonesia karena yang salah satu tugas memediasi pihak yang kelebihan dana dengan pihak yang membutuhkan. Sampai saat ini terdapat 43 perbankan yang sudah go public atau memberikan pilihan bagi investor untuk membeli saham dari perbankan tersebut engan harapan akan memberikan suatu imbalan hasil (return). Imbalan tersebut dapat berupa pemberian dividen dan atau mendapatkan capital gain dari peningkatan harga saham yang dimiliki. Investor harus memperhatikan kinerja perusahaan perbankan untuk target keuntungan berupa deviden atau retrun saham atau capital gain

Sector perbankan selama 6 tahun (2014 sampai dengan 2019) mempunyai perkembangan return saham perbankan yang fluktuatif. Hal ini ditunjukkan dengan terjadinya beberapa penurunan dan peningkatan. Selama periode penelitian (6 tahun) terjadi sebanyak 3 kali, yaitu terjadi pada tahun 2015, 2018 dan 2019. Sementara untuk peningkatannya terjadi pada tahun 2014, 2016 dan 2017. Kondisi seperti ini menjadi pertimbangan dalam pemilihan obyek penelitian pada sektor perbankan yang yg public di Indonesia.

Investor menginvestasikan dananya dengan membeli saham pada suatu perusahaan yang tercatat di BEI untuk memperoleh return atau pendapatan dari investasi yang dilakukannya. Bagi investor yang telah menanamkan dananya untuk membeli saham pada sector perbankan berharap akan memberikan suatu imbalan hasil (return). Imbalan tersebut dapat berupa pemberian dividen dan atau mendapatkan capital gain dari peningkatan harga saham yang dimiliki. Investor harus memperhatikan kinerja perusahaan perbankan untuk target keuntungan berupa deviden atau return saham atau capital gain (Sunaryo, 2020).

Banyak faktor yang mempengaruhi return saham perbankan diantaranya adalah capital adequacy ratio (CAR) atau merupakan rasio kecukupan modal dari perbankan. Hasil penelitian Setyarini dan Rahyuda (2017) menunjukkan bahwa CAR mempunyai pengaruh yang positif dan signifikan terhadap return saham perbankan. Setiap peningkatan kecukupan modal akan berdampak pada peningkatan return saham (Patricia dkk, 2021). Hasil berbeda ditunjukan oleh Sambul dkk (2016) bahwa CAR tidak berpengaruh signifikan terhadap return saham. Hasil berbeda lagi ditunjukkan oleh Purnamasari dkk (2017) dan Laynita dkk (2021) dimana peningkatan CAR justru berdampak pada penurunan return saham perbankan.

Return on equity ( $R O E$ ) merupakan rasio laba setelah pajak dibandingkan dengan modal sendiri. Hasil penelitian dari Rahmani (2019) menunjukkan bahwa return on equity (ROE). Hasil penelitian ini didukung oleh Hendayana dan Nurlina (2020) peningkatan $R O E$ akan berdampak pada peningkatan kembalian saham (return saham). Hasil penelitian ini bertolak belakang dengan penelitian dari Rohmat (2016) dan Purnamasari (2017) dimana ROE berpengaruh positif akan tetapi tidak signifikan pada return saham. Perbedaan juga ditunjukkan oleh Yudistira dan Adiputra (2020) bahwa peningkatan ROE justru berdampak pada penurunan return saham perbankan yang go public.

Loan to deposit ratio (LDR) merupakan rasio perbandingan antara pemberian pinjaman kepada pihak ketiga dengan dana simpanan dari pihak ketiga pada perbankan. Hasil penelitian dari Gantino dan Maulana (2013) yang menunjukkan bahwa loan to deposit ratio $(L D R)$ mempunyai pengaruh negative terhadap return saham. Hasil 
penelitian ini didukung oleh Sambul, dkk (2016) peningkatan LDR dapat menurunkan return saham. Hasil penelitian berbeda ditunjukkan oleh Jaya (2015) dimana LDR tidak berdampak terhadap return saham. Perbedaan penelitian juga ditunjukan oleh Patricia dkk (2021) dimana peningkatan rasio LDR berdampak pada peningkatan return saham. Perbankan yang berani memberikan kredit kepada debitur (dengan pertimbangan matang) berdampak pada kembalian saham oleh investor.

Hasil penelitian diatas menunjukkan adanya gap antara capital adequacy ratio $(C A R)$, return on equity $(R O E)$ dan loan to deposit ratio $(L D R)$ terhadap return saham memerlukan perbaikan model. Hasil penelitian dari Astohar (2020) memberikan rekomendasi untuk memperbaiki model dengan model yang bertingkat (intervening ataupun moderating). Dari kedua peneliti tersebut diharapkan dapat menyempurnakan penelitian dengan menambah variable bebas lainnya dan mengembang model menjadi structural.

Pada penelitian ini mencoba menutup gap penelitian dengan menambah varaibel intervening yaitu price book value $(P B V)$. Pemilihan variable tersebut hasil rekomendasi dari penelitian sebelumnya Memasukan variable price to value $(P B V)$ sebagai variable interveing yang memediasi pengaruh variable return on equity (ROE) dan loan to deposit ratio terhadap return saham diharapkan mampu menyempurnakan hasil penelitian sebelumnya. Sehingga model penelitian yang baru adalah model structural atau bertingkat. Tujuan dari penelitian ini adalah untuk mengetahui pengaruh secara langsung antara return on equity (ROE) dan loan to deposit ratio (LDR) secara langsung terhadap return saham perbankan go public di Indonesia ataupun yang dimediasi oleh price book to value.

\section{LANDASAN TEORI DAN PENGEMBANGAN HIPOTESIS}

\section{Landasan Teori}

Signaling theory merupakan cara pandang dari investor berkenaan dengan prospek perusahaan dalam peningkatan nilainya untuk masa yang akan mendatang (Brigham dan Houtson, 2014, dalam Hariyani dkk 2021). Teori signaling merupakan sinyal informasi yang dibutuhkan oleh para investor untuk menentukan apakah investor tersebut akan menanamkan sahamnya. Teori ini berfungsi memberikan kemudahan bagi investor untuk mengembangkan sahamnya yang dibutuhkan oleh manajer perusahaan dalam menentukan arah atau prospek kedepannya. Informasi yang dipublikasikan sebagai suatu pengumuman akan memberikan sinyal bagi investor dalam pengambilan keputusan investasi.

Jika pengumuman tersebut mengandung nilai positif, maka diharapkan pasar akan bereaksi pada waktu pengumuman tersebut diterima oleh pasar. Reaksi pasar ditunjukkan dengan adanya perubahan volume perdagangan saham yang dikarenakan investor menggunakan informasi yang ada untuk dianalisis sehingga terjadi perubahan volume perdagangan saham (Sunardi, 2010). Harapannya adalah pasar mampu membedakan adanya perusahaan yang memiliki kualitas yang baik ataupun buruk. Sinyal perusahaan tersebut efektif harus segera ditangkap pasar dan dipersepsikan baik, juga tidak mudah untuk ditiru perusahaan yang memiliki kualitas yang kurang baik 


\section{Pengembangan Hipotesis}

\section{Return Saham}

Return saham adalah hasil yang diperoleh oleh para investor dari tindakan investasi. Lestari, dkk (2016) return saham adalah suatu tingkat pengembalian saham yang diharapkan atas investasi yang dilakukan dalam saham atau beberapa kelompok saham melalui suatu portofolio. Semakin menarik return yang diberikan perusahaan, maka semakin besar juga niat investor dalam menanamkan modalnya (Artik, 2009, dalam Wahyuningsih dan Susestyo, 2020). Komponen return terdiri dari Yield (mencerminkan aliran kas atau pendapatan yang diperoleh secara periodik dari suatu investasi), dan Capital Gain/Loss (kenaikan/penurunan harga suatu surat berharga yang memberikan keuntungan/kerugian bagi investor.

\section{Price Book to Value}

Price book to value $(P B V)$ atau nilai perusahaan menurut (Lifessy, 2011 dalam Nuryana, 2017) menyebutkan bahwa diciptakan oleh perusahaan melalui kegiatan perusahaan dari waktu ke waktu agar mencapai nilai perusahaan yang maksimum diatas nilai buku. Nilai perusahaan merupakan persepsi investor terhadap perusahaan yang sering dikaitkan dengan harga saham. Harga saham yang tinggi membuat nilai perusahaan juga tinggi. Nilai perusahaan adalah gambaran kondisi kinerja suatu perusahaan yang mempengaruhi penilaian pasar maupun investor terhadap perusahaan. Jika kinerja keuangan baik maka yield/ return yang diperoleh akan berdampak besar kepada kemakmuran pemiliknya (Nagara dan Syafitri, 2018). Menurut Nurlela dan Islahudin (2008, dalam Nuryana, 2017) menjelaskan nilai perusahaan dapat memberikan kemakmuran pemegang saham secara maksimum apabila harga saham perusahaan meningkat. Semakin tinggi harga saham, maka akan tinggi kemakmuran pemegang saham.

\section{Capital adequacy Ratio}

Pada perusahaan perbankan, proksi yang digunakan untuk mengetahui tingkat kecukupan modal adalah capital ddequacy ratio (CAR) (Setyarini dan Rahyuda, 2017). Capital adequacy ratio (CAR) adalah rasio yang memperlihatkan seberapa jauh seluruh aktiva bank yang mengandung risiko (kredit, penyertaan, surat berharga, tagihan pada bank lain) ikut dibiayai dari dana modal sendiri bank, disamping memperoleh dana-dana dari sumber-sumber di luar bank, seperti dana masyarakat, pinjaman (utang), dan lainlain (Dendawijaya, 2009 dalam Laynita, 2021). Bank Indonesia mewajibkan setiap bank umum menyediakan modal minimum sebesar $8 \%$ dari total aktiva tertimbang menurut risiko (ATMR).

Hasil penelitian dari Setyarini dan Rahyuda (2017) bahwa ada pengaruh yang positif dan signfikan antara CAR terhadap return saham. Lebih lanjut Juliana dkk (2019) dan Patricia dkk (2021) memberikan gambaran bahwa perbankan yang mempunyai rasio kecukupan modal yang tinggi akan berdampak pada return saham. Hasil penelitian lain ditunjukkan oleh Sulastiningsih dan Sholihati (2018) bahwa CAR mempunyai dampak terhadap price book to value $(P B V)$. Dimana kemampuan bank dalam kecukupan modal dapat meningkatkan nilai perbankan itu sendiri (Anwar, 2016). Berdasarkan hasil penjelasan diatas dapat diajukan hipotesis $1\left(\mathrm{H}_{1}\right)$ dan hipotesis $4\left(\mathrm{H}_{4}\right)$. 
$H_{1}$ : Capital adequacy ratio (CAR) berpengaruh positif dan signifikan terhadap return saham pada perbankan yg go public

$\mathrm{H}_{4}$ : Capital adequacy ratio (CAR) berpengaruh positif dan signifikan terhadap return saham pada perbankan yg go public

\section{Return on Equity (ROE)}

Return on equity (ROE) digunakan untuk mengukur besarnya pengembalian terhadap investasi para pemegang saham. Angka tersebut menunjukkan seberapa baik manajemen memanfaatkan investasi para pemegang saham. Tingkat ROE memiliki hubungan yang positif dengan harga saham, sehingga semakin besar ROE semakin besar pula harga pasar, karena besarnya ROE memberikan indikasi bahwa pengembalian yang akan diterima investor akan tinggi sehingga investor akan tertarik untuk membeli saham tersebut, dan hal itu menyebabkan harga pasar saham cenderung naik (Harahap: 2007 dalam Rahmani, 2019).

Hasil penelitian dari Rahmani (2019) menunjukkan bahwa return on equity (ROE) mempunyai dampak positif terhadap return saham. Lebih lanjut penelitian dari Hendayana dan Nurlina (2020) menunjukkan bahwa kemampuan bank dalam mencetak laba bersih dibanding dengan modal sendiri berdampak terhadap return saham perbankan go public di Indonesia. Hasil penelitian lain dari Nagara dan Syafitri (2018) yang menunjukkan bahwa return on equity ( $R O E)$ mempunyai pengaruh positif terhadap price book to value $(P B V)$. Kemampuan perusahaan dalam mengoptimalkan modal sendiri berdampak terhadap peningkatan nilai perusahaan (Virolita dan Yuliana, 2020). $\left(\mathrm{H}_{5}\right)$.

Berdasarkan hasil penjelasan diatas dapat diajukan hipotesis $2\left(\mathrm{H}_{2}\right)$ dan hipotesis 5

$\mathrm{H}_{2}$ : Return on equity (ROE) berpengaruh positif dan signifikan terhadap return saham pada perbankan yg go public

$H_{5}:$ Return on equity (ROE) berpengaruh positif dan signifikan terhadap price book to value $(P B V)$ perbankan yg go public

\section{Loan to deposit Ratio (LDR)}

Loan to Deposit Ratio (LDR) adalah rasio yang digunakan untuk mengukur komposisi jumlah kredit yang diberikan dibandingkan dengan jumlah dana masyarakat dan modal sendiri yang digunakan (Sulastiningsih dan Sholihati, 2018) atau juga dibandingkan dengan dana pihak ketiga yang diterima bank (Astohar dkk, 2020). Loan to Deposit Ratio (LDR) digunakan untuk mengetahui tingkat kemampuan bank dalam menyelesaikan kewajiban jangka pendeknya. LDR merupakan rasio antara kredit yang diberikan dengan dana pihak ketiga. Total dana pihak ketiga terdiri dari berbagai bentuk yang tercantum dalam laporan keuangan perusahaan perbankan yaitu rekening giro, tabungan dan deposito berjangka (Purnamasari, dkk, 2017).

Hasil penelitian dari Sambul, dkk (2016) menunjukkan bahwa loan to deposit ratio $(L D R)$ mempunyai pengaruh negative terhadap return saham. Peningkatan bank dalam memberikan pinjaman kepada pihak ketiga (debitur) yang dibandingkan dengan dana pihak ketiga yang masuk berdampak terhadap penurunan return saham perbankan go public di Indonesia (Gantino dan Maulana (2013). Hasil penelitian lainnya dari Srihayati, dkk (2017) menunjukkan bahwa loan to deposit ratio (LDR) mempunyai pengaruh negative dan signifikan terhadap price book to value $(P B V)$. Peningkatan bank dalam memberikan pinjaman kepada pihak ketiga (debitur) yang dibandingkan dengan dana 
pihak ketiga yang masuk dengan tanpa dikendalikan berdampak terhadap penurunan nilai perbankan yang go public di Indonesia (Halimah dan Komariah (2017)

Berdasarkan hasil penjelasan diatas dapat diajukan hipotesis $3\left(\mathrm{H}_{3}\right)$ dan hipotesis 6 $\left(\mathrm{H}_{6}\right)$

$H_{3}$ : loan to deposit ratio (LDR) berpengaruh negative dan signifikan terhadap return saham pada perbankan yg go public

$H_{6}$ : loan to deposit ratio (LDR) berpengaruh negative dan signifikan terhadap price book to value (PBV) perbankan yg go public

Hasil penelitian dari Antara dan Suryantini (2019) yang melakukan penelitian pada perusahaan yang terindeks LQ 45 di Bursa Efek Indonesia menunjukkan bahwa price book to value mempunyai dampak positif terhadap return saham. Lebih lanjut penelitian dari Pandaya, dkk (2020) melakukan penelitian pada perusahaan yang terindek LQ 45. Hasil penelitian menunjukkan bahwa kemampuan bank dalam meningkatkan nilai perusahaan berdampak terhadap peningkatan return saham perbankan go public di Indonesia.

Berdasarkan pernyataan diatas dapat diajukan hipotesis $7\left(\mathrm{H}_{7}\right)$ sebagai berikut :

$H_{7}$ : price book to value $(P B V)$ berpengaruh positif dan signifikan terhadap return saham perbankan yg go public

\section{MODEL PENELITIAN}

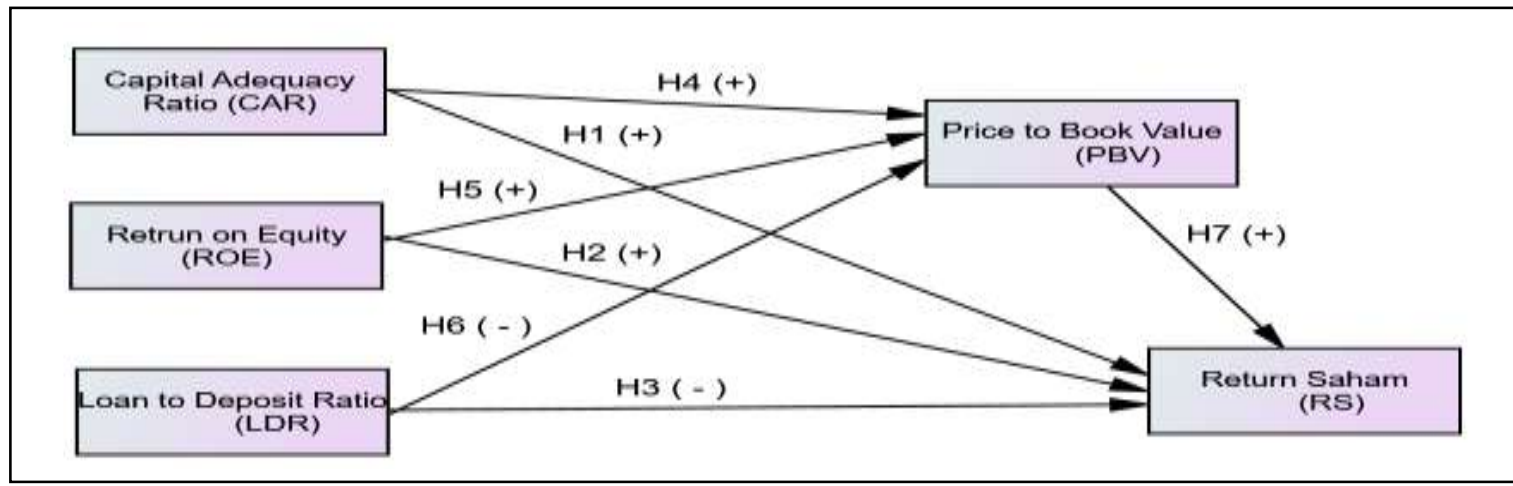

Gambar 1 Model Penelitian

\section{METODE PENELITIAN}

\section{Definisi Konsep dan Operasional Variabel}

\section{1) Capital Adequacy Ratio (CAR)}

Capital adequacy ratio (CAR) adalah kecukupan modal yang menunjukkan bank dalam mempertahankan modal yang mencukupi dan kemampuan manajemen bank dalam mengidentifikasi, mengukur, mengawasi, dan mengontrol resiko-resiko yang timbul yang dapat berpengaruh terhadap besarnya modal bank (Laynita dkk, 2021).

\section{2) Loan to deposit ratio (LDR)}

$$
\mathrm{CAR}=\frac{\text { Modal }}{\text { Aktiva Tertimbang Menurut Risiko }} \times 100 \%
$$

Loan to deposit ratio $(L D R)$ adalah rasio kinerja bank untuk mengukur likuiditas bank dalam memenuhi kebutuhan dana yang ditarik oleh masyarakat dalam bentuk tabungan, giro dan deposito. Rasio ini menunjukan salah satu penilaian likuiditas bank dan dapat dirumuskan sebagai berikut : (Sulastiningsih dan Sholihati, 2019) : 


$$
\text { LDR }=\frac{\text { Pembiayaan }}{\text { Total Dana Pihak Ketiga }+ \text { modal Inti }} \times 100 \%
$$

\section{3) Return on equity (Profitabilitas Bank Go Public)}

Return on equity (ROE) adalah rasio yang digunakan untuk mengukur keuntungan bersih yang diperoleh dari pengelolaan modal yang diinvestasikan oleh pemilik perusahaan. ROE diukur dengan perbandingan antara laba bersih dengan total modal. ROE diukur sebagai berikut (Rahmani, 2019):

\section{4) Price Book to Value}

$$
\mathrm{ROE}=\frac{\text { Laba Setelah Pajak }}{\text { Modal sendiri }} \times 100 \%
$$

Nilai perusahaan menggambarkan seberapa baik atau buruk manajemen mengelola kekayaannya, hal ini bisa dilihat dari pengukuran kinerja keuangan yang diperoleh. Price to Book Value adalah rasio yang bertujuan menunjukkan perbandingan harga saham terhadap nilai buku saham. Price book to value diukur dengan rumus sebagai berikut (Ardimas dan Wardoyo, 2014).

\section{5) Return saham}

$$
\begin{gathered}
\mathrm{PBV}=\frac{\text { Harga Saham }}{\text { Nilai buku Saham }(B V)} \\
\mathrm{BV}=\frac{\text { (Total Aktiva }- \text { Total hutang }}{\text { Saham beredar }}
\end{gathered}
$$

Return saham adalah tingkat keuntungan yang dinikmati oleh pemodal atas suatu investasi yang dilakukannya. Dalam teori pasar modal, tingkat pengembalian yang diterima oleh seorang investor dari saham yang diperdagangkan di pasar modal (saham perusahaan go public) biasa diistilahkan dengan return saham. Untuk return saham perhitungannya menggunakan Capital gain (loss) yaitu keuntungan atau kerugian yang didasarkan pada penutupan harga saham periode sekarang dengan periode sebelumnya. Rumus return saham adalah sebagai berikut (Pandaya dkk (2020)

$$
\mathrm{Rt}=\frac{\mathrm{Pt}-\mathrm{Pt}-1}{P t-1}
$$

$\mathrm{Rt}=$ Return saham pad aperiode ke-t

$\mathrm{Pt}=$ harga saham periode pengamatan

Pt-1 = harga saham periode pengamatan sebelumnya

\section{Populasi dan Sampel}

Populasi dalam penelitian ini adalah sebanyak 43 perbankan yang tercatat sampai dengan tahun 2019. Pemilihan sampel dilakukan dengan menggunakan metode purposive sampling (pertimbangan tertentu) yaitu dengan pertimbangan yaitu pada tahun 2014 2019 tersedia data dengan lengkap. Pengumpulan data menggunakan panel data selama 6 tahun periode penelitian. Berdasarkan pertimbangan - pertimbangan diatas data yang digunakan sebagai sampel adalah 35 perbankan selama 6 tahun atau 210 observasi.

\section{Jenis dan Metode Pengumpulan Data}

Data yang digunakan adalah berupa laporan keuangan publikasi tahunan yang diterbitkan oleh Bank Indonesia yang diperoleh dari WEB OJK dari periode tahun 2014 sampai tahun 2019 dan dari WEB IDX. Sumber data yang digunakan ini diperoleh melalui penelusuran dari media internet dari www.ojk.go.id dan WEB Bursa Eek Indonesia. Metode pengumpulan data yang digunakan yaitu melalui studi pustaka dari 
direktori perusahaan go publik dan situs resmi tiap perusahaan.idx.go.id. serta situs - situs resmi lainnya yang dijadikan sampel.

\section{Alat Analisis Data}

\section{Uji Persamaan Regresi Ganda Tahap 1}

Analisis regresi linier berganda adalah pengaruh secara linier antara dua atau lebih variabel bebas (independen) dengan satu variabel dependen, yaitu pengaruh dari capital adequacy ratio (CAR), return on equity (ROE) dan loan to deposit ratio (LDR) terhadap price book to value (PBV) (Ghozali, 2018).

Persamaan regresi pada penelitian ini terdapat dua model. yaitu sebagai berikut :

$$
Y_{1}=a+b_{1} X_{1}+b_{2} X_{2}+b_{3} X_{3}
$$

Dimana :

$\mathrm{Y}_{1}: \mathrm{PBV}$

$\mathrm{X}_{1}: \mathrm{CAR}$

$\mathrm{X}_{2}: \mathrm{ROE}$

$\mathrm{X}_{3}: \mathrm{LDR}$

\section{Uji Persamaan Regresi Ganda tahap 2}

Analisis regresi linier berganda adalah pengaruh secara linier antara dua atau lebih variabel independen dengan satu variabel dependen, yaitu pengaruh dari capital adequacy ratio $(C A R)$, return on equity $(R O E)$ dan loan to deposit ratio $(L D R)$ terhadap return saham (ROA). Sebelum melakukan estimasi yang tidak biasa dengan analisis regresi, perlu dilakukan uji t dan uji Fit data yaitu pengujian antar variabel bebas supaya tidak terjadi multikolinieritas, heteroskedastisitas, normalitas, dan autokorelasi (Ghozali, 2018).

Persamaan regresi pada penelitian ini terdapat dua model. yaitu sebagai berikut :

$$
\mathrm{Y}_{2}=\mathrm{a}+\mathrm{b}_{1} \mathrm{X}_{1}+\mathrm{b}_{2} \mathrm{X}_{2}
$$

Dimana :

$\mathrm{Y}_{2}: \mathrm{RS}$

$\mathrm{X}_{1}: \mathrm{CAR}$

$\mathrm{X}_{2}: \mathrm{ROE}$

$\mathrm{X}_{3}: \mathrm{LDR}$

\section{Uji Persamaan Regresi Sederhana}

Analisis regresi linier sederhana adalah pengaruh secara linier antara variabel independen dengan variabel dependen, yaitu pengaruh dari price book to vale (PBV) terhadap Return saham (RS) (Astohar, 2013).

Persamaan regresi pada penelitian ini terdapat dua model. yaitu sebagai berikut:

$$
Y_{2}=a+b_{5} Y_{1}
$$

Dimana :

$\mathrm{Y}_{2}: \mathrm{RS}$

$\mathrm{Y}_{1}: \mathrm{PBV}$

\section{Uji Koefisien Determinasi}

Koefisien determinan pada penelitian ini digunakan untuk melihat berapa persen dari variasi variabel terikat dijelaskan variabel bebas. Pada penelitian ini koefisien 
determinasi adalah mengetahui seberapa besar variasi return saham bank go public dapat diterangkan oleh variasi dari return on equity ( $R O E)$, loan to deposit ratio (LDR) dan price book to value (PBV). Nilai determinasi yang digunakan pada penelitian ini adalah nilai $R^{2}$. Digunakannya nilai tersebut karena nilai $R^{2}$ pada saat mengevaluasi model regresi dapat naik atau turun apabila satu variabel independen ditambahkan ke dalam model (Ghozali, 2018).

\section{Sobel Test}

Uji Sobel ini dilakukan dengan cara menguji kekuatan pengaruh tidak langsung variabel independen $(\mathrm{X})$ kepada variabel dependen $(\mathrm{Y})$ melalui variabel intervening $(\mathrm{M})$ dalam hal ini adalah menguji pengaruh tidak langsung variabel return on equity ratio $(R O E)$ dan loan to deposit ( $L D R)$ secara tidak langsung terhadap return saham melalui price book to value. Suatu variabel disebut variabel intervening jika variabel tersebut ikut mempengaruhi hubungan antara variabel prediktor (independen) dan variabel criterion (dependen) (Baron dan Kenny (1986) dalam Ghozali (2009). Pengujian hipotesis mediasi dapat dilakukan dengan prosedur yang dikembangkan oleh Sobel (1982) dan dikenal dengan Uji Sobel (Sobel Test).

Berdasarkan hasil perhitungan diperoleh hasil sebagai berikut :

Kriteria pengambilan keputusan :

Apabila $t$ sobel $>\mathrm{t}$ tabel : variabel terbukti sebagai variabel intervening

Apabila $\mathrm{t}$ sobel $<\mathrm{t}$ tabel : variabel tidak terbukti sebagai variabel intervening

\section{HASIL DAN PEMBAHASAN}

\section{Analisis Deskriptif}

Pada data 210 observasi tidak terdistribusi secara normal, setelah mengeluarkan 10 observasi melalui tahapan screening data menjadi normal. Data yang diolah adalah 190 observasi.

\begin{tabular}{lccccc}
\multicolumn{5}{c}{ Tabel 1 : Deskriptif Variabel } \\
Descriptive Statistics & \\
\hline N & Minimum & Maximum & Mean & Std. Deviation \\
\hline CAR & 190 & 10.44 & 148.28 & 21.6764 & 11.20805 \\
ROE & 190 & -89.03 & 31.22 & 6.0747 & 14.71153 \\
LDR & 190 & 47.54 & 169.76 & 88.2227 & 16.27922 \\
PBV & 190 & 0.0000 & 4.79 & 1.5150 & 0.92026 \\
RS & 190 & -0.5579 & 0.9980 & 0.033795 & 0.30000 \\
Valid N (listwise) & 190 & & & & \\
\hline
\end{tabular}

Pada variable capital adequacy ratio $(C A R)$ rata-ratanya adalah sebesar 21,68 yaitu masuk dalam kategori capital adequacy ratio adalah sehat $(>8)$. Pada variable return on equity (ROE) rata-ratanya adalah sebesar 6,07 yaitu masuk dalam kategori Return on equity adalah kurang baik $(<10)$. Pada variabel loan to deposit ratio $(L D R)$ masuk dalam kategori yang sehat (85\% sampai dengan $110 \%$ ). Price book to value (PBV) ini menunjukkan bahwa berdasarkan rata - rata Bank Go Public masuk dalam kategori yang kurang bagus, hal ini ditandai dengan rata - rata price book to value masih dikisaran 1,51 $\%$. Pada variable return saham bank go public yang rata-ratanya adalah sebesar 0,034 . Berdasarkan rata - rata, Bank Go Public masuk dalam kategori saham mempunyai tingkat 
kembalian yang kurang baik. Hal ini ditandai dengan rata - rata return saham Bank Go Public masih dibawah 1.

\section{Uji Normalitas dan Penyimpangan Asumsi Klasik}

Pada awalnya data penelitian sebanyak 210 observasi tidak terdistribusi secara normal. Setelah mengeluarkan 20 data (tersisa 190 observasi) dengan mengikuti rekomendasi dari program SPSS data yang digunakan untuk penelitian terdistribusi secara normal. Hal ini ditandai dengan print out grafik terlihat titik-titiknya nampak menyebar mendekat atau berada disekitar pada garis diagonal, serta penyebaran titik - titiknya mengikuti garis diagonal. Selain pada grafik histogram yang menunjukkan data tersebar mendekati garis normalitas. Berdasarkan uji Kolmogorov Smirnov sebesar 0,119 yang mana nilai signifikansi tersebut lebih besar dari nilai signifikansi yang telah ditentukan yaitu 0,05. Berdasarkan data tersebut dapat dijelaskan bahwa model regresi telah terdistribusi secara normal.

Hasil pengujian penyimpangan asumsi klasik menunjukkan bahwa model tidak terjadi penyimpangan multikolinearitas yang ditandai dengan nilai VIF dibawah 10 yaitu : 1,$273 ; 1,334 ; 1,105$ dan 1,130 serta nilai tolerance diatas 0,1 yaitu 0,$786 ; 0,750 ; 905$ dan 0,885 . Grafik scatterplot tidak membentuk pola yang khusus atau jelas, hal ini menunjukkan data tidak terjadi penyimpangan heteroskedastisitas. Nilai durbin Watson sebesar 2,014 yang mana nilai tersebut berada pada daerah tidak tidak terjadi autokorelasi.

\section{Uji Goodnes of Fit}

Hasil perhitungan anova didapatkan nilai $F$ hitungnya sebesar 7,246 nilai probabilitas adalah 0,000. Hasil ini dikatakan bahwa permodelan yaitu variabel bebas yang berupa CAR, ROE, LDR dan PBV secara bersama - sama (simultan) mempunyai pengaruh signifikan terhadap return saham pada Bank yang Go Public, atau model yang dibangun memenuhi kriteria fit. Hal ini dapat diberikan penjelasan bahwa model yang dibangun memenuhi kriteria goodness of fit.

\section{Analisis Regresi Linier Berganda Tahap 1}

\section{Tabel 2 : Persamaan Regresi Tahap 1}

Coefficients $^{\mathrm{a}}$

\begin{tabular}{|c|c|c|c|c|c|c|c|}
\hline & \multirow{2}{*}{ Model } & \multicolumn{2}{|c|}{$\begin{array}{c}\text { Unstandardized } \\
\text { Coefficients }\end{array}$} & \multirow{2}{*}{$\begin{array}{c}\begin{array}{c}\text { Standardized } \\
\text { Coefficients }\end{array} \\
\text { Beta }\end{array}$} & \multirow{2}{*}{$\mathbf{t}$} & \multirow{2}{*}{ Sig. } & \multirow{2}{*}{ Ket } \\
\hline & & B & $\begin{array}{c}\text { Std. } \\
\text { Error }\end{array}$ & & & & \\
\hline \multirow{4}{*}{1} & (Constant) & 2.166 & 0.395 & & 5.486 & 0.000 & \\
\hline & CAR & 0.017 & 0.006 & 0.204 & 2.679 & 0.008 & $\mathrm{H}_{4}$ diterima \\
\hline & $\mathrm{ROE}$ & 0.018 & 0.005 & 0.287 & 3.738 & 0.000 & $\mathrm{H}_{5}$ diterima \\
\hline & LDR & -0.013 & 0.004 & -0.225 & -3.194 & 0.002 & $\mathrm{H}_{6}$ diterima \\
\hline
\end{tabular}

a. Dependent Variable: PBV

$$
\mathrm{PBV}=2,166+0,017 \mathrm{CAR}+0,018 \mathrm{ROE}-0,013 \mathrm{LDR}
$$

Nilai konstanta pada penelitian ini diperoleh nilai 2,166 yang dapat diartikan bahwa tanpa adanya perubahan dari variabel bebas atau variabel capital adequacy ratio (CAR), return on equity (ROE) dan loan to deposit ratio (LDR) maka nilai perusahaan (price book to value) pada Bank Go Public mengalami peningkatan 
Capital Adequacy ratio (CAR) Bank Go Public di Indonesia mempunyai pengaruh positif terhadap nilai perusahaan (price book to value) dengan koefisien regresi sebesar 0,017 . Hal ini dapat diartikan bahwa setiap peningkatan return on equity (ROE) maka nilai perusahaan (price book to value) pada Bank Go Public di Indonesia mengalami peningkatan pula. Hipotesis $4\left(\mathrm{H}_{4}\right)$ diterima, karena ditunjukkan dengan nilai probabilitas (sig) sebesar 0,008 yang mana nilai tersebut dibawah 0,05 atau nilai t hitung sebesar 2,679 yang mana lebih dari t tabel $(1,96)$.

Hasil penelitian ini sejalan dengan penelitian dari Sulastiningsih dan Sholihati (2018) bahwa capital adequacy ratio mempunyai pengaruh yang positif dan signifikan terhadap return saham perbankan yang go public di Indonesia. Hal ini menunjukkan bahwa semakin tinggi rasio kecukupan modal akan berdampak pada meningkatnya nilai perusahaan, hasil ini sejalan dengan penelitian dari Anwar (2016) bahwa perbankan yang hati - hati dalam mengantisipasi aktiva tertimbang menurut risiko akan berdampak pada nilai dari perusahaan atau perbankan yang go public tersebut.

Return on equity ( $R O E$ ) Bank Go Public di Indonesia mempunyai pengaruh positif terhadap nilai perusahaan (price book to value) dengan koefisien regresi sebesar 0,018. Hal ini dapat diartikan bahwa setiap peningkatan return on equity (ROE) maka nilai perusahaan (price book to value) pada Bank Go Public di Indonesia mengalami peningkatan pula. Hipotesis $5\left(\mathrm{H}_{5}\right)$ diterima, karena ditunjukkan dengan nilai probabilitas (sig) sebesar 0,000 yang mana nilai tersebut dibawah 0,05 atau nilai t hitung sebesar 3,738 yang mana lebih dari t tabel $(1,96)$.

Hasil penelitian ini sejalan dengan penelitian dari Nagara dan Syafitri (2018) bahwa return on equity mempunyai pengaruh yang positif dan signifikan terhadap return saham perbankan yang go public di Indonesia. Hal ini menunjukkan bahwa semakin tinggi kemampuan dalam mencetak laba bersih setelah pajak dibandingkan dengan modal sendiri akan berdampak pada meningkatnya nilai perusahaan, hasil ini sejalan dengan penelitian dari Virolita dan Yuliana (2020) bahwa perbankan yang mampu mencetak laba bersih setelah pajak akan berdampak pada nilai dari perusahaan atau perbankan yang go public tersebut.

Loan to deposit ratio $(L D R)$ Bank Go Public di Indonesia mempunyai pengaruh negatif terhadap nilai perusahaan (price book to value) dengan koefisien regresi sebesar - 0,013. Hal ini dapat diartikan bahwa setiap peningkatan Loan to deposit ratio (LDR) maka nilai perusahaan (price book to value) pada Bank Go Public di Indonesia mengalami penurunan. Hipotesis $6\left(\mathrm{H}_{6}\right)$ diterima, karena ditunjukkan dengan nilai probabilitas $(\mathrm{sig})$ sebesar 0,002 yang mana nilai tersebut dibawah 0,05 atau nilai t hitung sebesar -3,194 yang mana masih kurang dari t tabel $(-1,96)$.

Hasil penelitian ini sejalan dengan penelitian yang dilakukan oleh Srihayati (2015) bahwa loan to deposit ratio $(L D R)$ mempunyai pengaruh yang negatif dan signifikan terhadap return saham perbankan yang go public. Peningkatan perbankan dalam menyalurkan kredit kepada para nasabah yang tidak diimbangi dengan dana pihak ketiga yang diterima bank akan berdampak pada penurunan nilai perusahaan. Hasil penelitian ini juga sejalan dengan penelitian yang dilakukan oleh Halimah dan Komariah (2017) perbankan yang over ekspansif dalam pemberian kredit akan berdampak pada penurunan nilai perbankan tersebut. 


\section{Analisis Regresi Linier Berganda Tahap 2}

Tabel 3 : Persamaan Regresi Tahap kedua

Coefficients $^{\mathrm{a}}$

\begin{tabular}{|c|c|c|c|c|c|c|c|}
\hline & \multirow{2}{*}{ Model } & \multicolumn{2}{|c|}{$\begin{array}{c}\text { Unstandardized } \\
\text { Coefficients }\end{array}$} & \multirow{2}{*}{$\begin{array}{c}\text { Standardized } \\
\text { Coefficients } \\
\text { Beta }\end{array}$} & \multirow{2}{*}{$\mathbf{t}$} & \multirow{2}{*}{ Sig. } & \multirow{2}{*}{ Ket } \\
\hline & & B & $\begin{array}{l}\text { Std. } \\
\text { Error }\end{array}$ & & & & \\
\hline \multirow{4}{*}{1} & (Constant) & 0.103 & 0.133 & & 0.777 & 0.438 & \\
\hline & CAR & 0.002 & 0.002 & 0.068 & 0.866 & 0.388 & $\mathrm{H}_{1}$ ditolak \\
\hline & ROE & 0.005 & 0.002 & 0.253 & 3.188 & 0.002 & $\mathrm{H}_{2}$ diterima \\
\hline & LDR & -0.002 & 0.001 & -0.086 & -1.186 & 0.237 & $\mathrm{H}_{3}$ ditolak \\
\hline
\end{tabular}

a. Dependent Variable: RS

$$
\mathrm{RS}=0,103+0,002 \mathrm{CAR}+0,005 \mathrm{ROE}-0,002 \mathrm{LDR}
$$

Nilai konstanta pada penelitian ini diperoleh nilai 0,145 yang dapat diartikan bahwa tanpa adanya perubahan dari variabel bebas atau variabel capital adequacy ratio $(C A R)$, return on equity (ROE) dan loan to deposit ratio (LDR) maka return saham pada Bank yang Go Public mengalami peningkatan

Capital adequacy ratio (CAR) Bank Go Public di Indonesia mempunyai pengaruh positif terhadap return saham pada Bank yang Go Public dengan koefisien regresi sebesar 0,002 . Hal ini dapat diartikan bahwa setiap peningkatan capital adequacy ratio (CAR) maka return saham pada Bank yang Go Public di Indonesia tidak selalu mengalami peningkatan. Hipotesis $1\left(\mathrm{H}_{1}\right)$ ditolak, karena ditunjukkan dengan nilai probabilitas (sig) sebesar 0,388 yang mana nilai tersebut diatas 0,05 atau nilai t hitung sebesar 0,866 yang mana t hitung lebih dari t tabel $(1,96)$.

Hasil penelitian ini sejalan dengan penelitan yang dilakukan oleh Sambul (2016) yang mana capital adequacy ratio (CAAR) mempunyai pengaruh positif tidak signifikan terhadap return saham pada perbankan go public. Hasil penelitian ini juga selaras dengan penelitian Laynita dkk (2021) dimana bank yang mempunyai kecukupan modal yang tinggi tidak berdampak pada permintaan saham oleh para investor, sehingga tidak ada dampaknya pada peningkatan kembalian saham oleh investor.

Return on equity (ROE) Bank Go Public di Indonesia mempunyai pengaruh positif terhadap return saham pada Bank yang Go Public dengan koefisien regresi sebesar 0,005. Hal ini dapat diartikan bahwa setiap peningkatan return on equity (ROE) maka return saham pada Bank yang Go Public di Indonesia mengalami peningkatan. Hipotesis $2\left(\mathrm{H}_{2}\right)$ diterima, karena ditunjukkan dengan nilai probabilitas (sig) sebesar 0,002 yang mana nilai tersebut dibawah 0,05 atau nilai $t$ hitung sebesar 3,188 yang mana $t$ hitung lebih dari $t$ tabel $(1,96)$.

Hasil penelitian ini sejalan dengan penelitan yang dilakukan oleh Rahmani (2019) yang mana return on equity ( $R O E$ ) mempunyai pengaruh positif terhadap return saham pada perbankan go public. Hasil penelitian ini juga selaras dengna penelitian Hendayana dan Nurlina (2020) dimana ada peningkatan kemampuan perbankan dalam menghasilkan laba setelah pajak yang dibandingkan dengan modal sendiri berdampak pada permintaan saham oleh para investor, sehingga dampaknya adalah adanya peningkatan kembalian saham oleh investor.

Loan to deposit ratio (LDR) Bank Go Public di Indonesia mempunyai pengaruh positif terhadap return saham pada Bank yang Go Public dengan koefisien regresi sebesar 0,001 . Hal ini dapat diartikan bahwa setiap peningkatan Loan to deposit ratio (LDR) maka return saham pada Bank yang Go Public di Indonesia mengalami penurunan. Hipotesis 3 
$\left(\mathrm{H}_{3}\right)$ ditolak, karena ditunjukkan dengan nilai probabilitas (sig) sebesar 0,237 yang mana nilai tersebut diatas 0,05 atau nilai t hitung sebesar $-1,186$ yang mana nilai $t$ htiung lebih dari t tabel $(-1,96)$.

Hasil penelitian ini sejalan dengan penelitian yang dilakukan oleh Jaya (2015) bahwa loan to deposit ratio (LDR) mempunyai pengaruh yang negative tapi tidak signifikan terhadap return saham pada Perbankan yang go public di Indonesia. Hal ini menunjukkan tingkat likuiditas berdampak terhadap penurunan return saham perbankan yang go public di Indonesia (Patricia, dkk, 2021). Meskipun hasil ini tidak signifikan, namun dapat dijadikan evaluasi bahwa keberanian bank dalam memberikan kredit yang melebihi dana pihak ketiga yang diterima diangap kurang prudent, hal ini berdampak pada kekhawatiran investor pada kemampuan bank dalam mengembalikan dana pihak ketiga. Dampak yang ditimbulkan adalah investor banyak melepas saham dan hal ini menurunkan return saham dari perbankan go public.

\section{Analisis Regresi Linier Tahap 3}

\section{Tabel 4 : Persamaan Regresi Tahap 3}

Coefficients $^{\mathbf{a}}$

\begin{tabular}{|c|c|c|c|c|c|c|c|}
\hline & \multirow{2}{*}{ Model } & \multicolumn{2}{|c|}{$\begin{array}{c}\text { Unstandardized } \\
\text { Coefficients }\end{array}$} & \multirow{2}{*}{$\begin{array}{c}\begin{array}{c}\text { Standardized } \\
\text { Coefficients }\end{array} \\
\text { Beta }\end{array}$} & \multirow{2}{*}{$\mathbf{t}$} & \multirow{2}{*}{ Sig. } & \multirow{2}{*}{ Ket } \\
\hline & & B & $\begin{array}{l}\text { Std. } \\
\text { Error }\end{array}$ & & & & \\
\hline \multirow{2}{*}{1} & (Constant) & -0.130 & 0.040 & & -3.280 & 0.001 & \\
\hline & PBV & 0.108 & 0.022 & 0.332 & 4.829 & 0.000 & $\mathrm{H}_{7}$ diterima \\
\hline
\end{tabular}

a. Dependent Variable: RS

$$
\mathrm{RS}=-0,130+0,108 \mathrm{PBV}
$$

Nilai konstanta pada penelitian ini diperoleh nilai - 0,130 yang dapat diartikan bahwa tanpa adanya perubahan dari variabel bebas atau variabel nilai perusahaan (price book to value) maka return saham pada Bank Go Public mengalami penurunan. Hal ini menunjukkan begitu pentingnya nilai perusahaan (perbankan), sehingga apabila variabel ini tetep atau tidak mengalami perubahan return saham perbankan akan mengalami penurunan.

Nilai perusahaan (price book to value) Bank Go Public di Indonesia mempunyai pengaruh positif dan signifikan terhadap return saham pada Bank yang Go Public dengan koefisien regresi sebesar 0,108 . Hal ini dapat diartikan bahwa setiap peningkatan nilai perusahaan (price book to value) maka return saham pada Bank yang Go Public di Indonesia mengalami peningkatan atau sebaliknya setiap penurunan nilai perusahaan (price book to value) juga akan menurunkan return saham pada Bank yang Go Public. Hipotesis diterima pada taraf $5 \%$, karena dibuktikan dengan nilai probabilitas (sig) sebesar 0,000 yang mana nilai tersebut dibawah 0,05 atau nilai t hitung sebesar 4,829 yang mana $t$ hitung lebih dari $t$ tabel $(1,96)$.

\section{Koefisien Determinasi}

Berdasarkan hasil perhitungan diperoleh nilai koefisien determinasi ( $R$ Square) sebesar sebesar 0,101. Besar variasi variabel nilai perusahaan (price book to value) pada Bank Go Public di Indonesia yang dapat diterangkan oleh variasi variabel capital adequacy ratio (CAR), return on equtiy (ROE) dan loan to deposit ratio (LDR) adalah sebesar $10,1 \%$, sedangkan sisanya sebesar $89,9 \%$ dipengaruhi oleh variabel lain di luar 
model penelitian. Besar variasi variabel return saham pada Bank yang Go Public di Indonesia yang dapat diterangkan oleh variasi variabel price book to value $(P B V)$ adalah sebesar $11,0 \%$, sedangkan sisanya sebesar $89,0 \%$ dipengaruhi oleh variabel lain di luar model penelitian

\section{Sobel Test}

\section{Peran price book to value (PBV) dalam Mediasi Pengaruh capital adequacy ratio} (CAR) terhadap Return saham

Berdasarkan hasil perhitungan diperoleh nilai t sobel test sebesar 2,454 dan nilai $t$ tabel sebesar 1,96. Perbandingan tersebut menunjukkan sobel test $>t$ tabel $(2,454>1,96)$ atau nilai sig $<$ alpha $(0,014<0,05)$ sehingga dapat dijelaskan bahwa ada peran price book to value $(P B V)$ dalam memediasi pengaruh capital adequacy ratio $(C A R)$ terhadap return saham pada perbankan yang go public. Hasil tersebut menunjukkan bahwa price book to value $(P B V)$ terbukti signifikan dalam memediasi pengaruh loan to deposit ratio terhadap return saham pada Bank yang Go Public.

\section{Peran Price book to value (PBV) dalam Mediasi Pengaruh Return on equity (ROE) terhadap Return saham}

Berdasarkan hasil perhitungan diperoleh nilai t sobel test sebesar 2,903 dan nilai $t$ tabel sebesar 1,96. Perbandingan tersebut menunjukkan sobel test $>t$ tabel $(2,903>1,96)$ atau nilai sig $<$ alpha $(0,004<0,05)$ sehingga dapat dijelaskan bahwa ada peran price book to value $(P B V)$ dalam memediasi pengaruh return on equity ( $R O E)$ terhadap return saham pada perbankan yang go public. Hasil tersebut menunjukkan bahwa price book to value $(P B V)$ terbukti signifikan dalam memediasi pengaruh loan to deposit ratio terhadap return saham pada Bank yang Go Public.

\section{Peran Price book to value (PBV) dalam Mediasi Pengaruh Loan to Deposit Ratio terhadap Return saham}

Berdasarkan hasil perhitungan diperoleh nilai t sobel test sebesar - 2,780 dan nilai - $\mathrm{t}$ tabel sebesar - 1,96. Perbandingan tersebut menunjukkan - sobel test $<-\mathrm{t}$ tabel $(-2,780$ $<-1,96)$ atau nilai sig < alpha $(0,007<0,05)$ sehingga dapat dijelaskan bahwa ada peran price book to value $(P B V)$ dalam memediasi pengaruh loan to deposit ratio terhadap return saham. Hasil tersebut menunjukkan bahwa price book to value $(P B V)$ terbukti signifikan dalam memediasi pengaruh loan to deposit ratio terhadap return saham pada Bank yang Go Public.

\section{PENUTUP}

Price to book value mampu memediasi pengaruh capital adequacy ratio (CAR), return on equity $(R O E)$ dan loan to deposit ratio $(L D R)$ terhadap return saham perbankan yang go public di Indonesia. Hal ini menunjukkan peran penting dari price book to value dalam menjembati pengaruh variable bebas terhadap variable terikat. Secara langsung capital adequacy ratio dan loan to deposit ratio tidak mampu mempengaruhi return saham perbankan yang go public.

Perbankan harus mampu meningkatkan nilai perbankan itu sendiri melalui pengembangan produk jasa keuangan seperti melakukan pendampingan atau kemitraan pada usaha - usaha mikro. Melakukan peningkatan platfon anggaran atau mengambil 
tindakan dalam penambahan kredit kepada debitur - debitur yang mempunyai track record yang baik dan prudent dalam penggunaan dananya. Memanfaatkan dana yang lebih (yang tidak terserap oleh pinjaman) dengan dimanfaatkan untuk membeli saham perbankan termasuk dimungkinkan perbankan milik sendiri untuk mengurangi dana menganggur di perbankan.

Untuk penelitian mendatang diharapkan model penelitian dapat dikembangkan lagi yaitu dengan menambah variabel intervening ataupun variabel moderating sekaligus. Selain itu obyek penelitian dapat diperluas lagi pada perbankan yang terdapat unit usaha yang lebih luas (semua bank di Indonesia) serta dapat juga dengan enambah variabel yang mempengaruhi return saham pada Bank yang Go Public.

\section{DAFTAR PUSTAKA}

Antara, I M., Yogi dan Suryantini, N.P.S. (2019). Pengaruh Rasio Pasar terhadap Return Saham pada Saham LQ-45 di Bursa Efek Indonesia, E-Jurnal Manajemen, 8 (9). 2302-8912

Antari, N. P. H., Yuesti, A dan Dewi, N. P. S (2020). Pengaruh Kinerja Keuangan terhadap Return Saham pada Perusahaan Manufaktur yang terdaftar di Bursa Efek Indonesia Periode 2016-2018. Jurnal Kharisma. 2 (1), 212 -221.

Anwar. (2016). Kajian Kinerja Keuangan dan Corporate Social Responsibility (CSR) terhadap Nilai Perusahaan pada Bank yang Terdaftar di Bursa Efek Indonesia Periode 2011 - 2015. Balance. XIII (2), 117 - 132

Ardimas, W dan Wardoyo. (2014). Pengaruh Kinerja Keuangan dan Corporate Social Responsibility terhadap Nilai Perusahaan pada Bank Go Public yang terdaftar di BEI., BENEFIT Jurnal Manajemen dan Bisnis., 18 (1). 57 - 66

Arista, D dan Astohar. (2012). Analisis Faktor - Faktor Yang Mempengaruhi Return Saham (Kasus pada Perusahaan Manufaktur yang Go Public di BEI periode tahun 2005 - 2009). Jurnal Ilmu Manajemen dan Akuntansi Terapan. 2 (1). 1 - 15.

Astohar. (2013). Statistika Bisnis Kasus dan Solusi. Semarang : Penerbit Duta Nusindo.

Astohar, Dhian A.M. S, dan Rahmadhani, S. (2020). Analisis Faktor - faktor yang Mempengaruhi Return Saham pada Perbankan yang Go Public di Bursa Efek Indonesia (BEI) pada Periode 2014 - 2019., Proseding Seminar Nasional Unimus. 3, $1045-1054$

Ghozali, I. (2018). Aplikas Analisis Multivariate dengan Program IBM SPSS 25., Edisi 9. Semarang : Badan Penerbit Universitas Diponegoro.

Gantino, R dan Maulana, F. (2013). Pengaruh ROA, CAR, dan LDR terhadap Return Saham pada Perusahaan Perbankan yang Terdaftar di Bursa Efek Indonesia Periode 2008-2012. Proceeding Seminar Nasional \& Call For Papers (SCA-3). 3 (1), 1 13.

Halimah, S.N dan Komariah, E. (2017). Pengaruh ROA, CAR, NPL, LDR, BOPO terhadap Nilai Perusahaan Bank Umum., Jurnal Akuntansi, Ekonomi dan Manajemen Bisnis., 5 (1), 14 - 25.

Hariyani, C. Burhanudin dan Damayanti, R. (2021). Analisis Kinerja Keuangan Terhadap Harga Saham (Pada Perusahaan Perbankan Yang Terdaftar Di Bursa Efek 
Indonesia Periode 2015-2019). Jurnal Ilmiah Bidang Ilmu Ekonomi (SOLUSI). 19 (1).

Hendayana, Y dan Nurlina. (2020). Pengaruh Economic Value Added dan Profitabilitas terhadap Return Saham pada Perusahaan Sub Sektor Perdagangan Ritel yang Terdaftar di BEI Periode 2013-2017. Kinerja Jurnal Ekonomi Dan Bisnis. 2 (2), $34-43$.

Jaya, K.A. (2015)., Pengaruh Loan To Deposite Ratio, Return On Assets, Capital Adequacy Ratio, Exchange Rate dan Interest Rate terhadap Return Saham, Jurnal Akuntansi/ XIX (3), 340-356

Juliana, S.F. Pahlevi, C dan Amar, Y. (2019). Faktor-Faktor yang Mempengaruhi Return Saham perusahaan Perbankan yang Terdaftar di BEI Periode 2012-2017. JBMI. 15 (3), $305-321$.

Nagara, P dan Syafitri, M. (2018). Pengaruh ROA, ROE, BOPO, NIM dan Corporate Social Responsibility (CSR) terhadap Nilai Perusahaan pada Perbankan yang terdaftar di Bursa Efek Indonesia Periode 2011-2015., Jurnal Indovisi, 1 (1), 1 17.

Laynita, S. Hilda, M. Elfiswandi. Zefriyenni dan Lusiana. (2021) Kinerja Perusahaan Dan Bi Rate Terhadap Return Saham Bank BUMN. Jurnal Ekonomi Manajemen Sistem Informasi. 2 (4), 544 - 555.

Lestari, K, Andini R dan Oemar, A, (2016). Analisis Likuiditas, Leverage, Profitabilitas, Aktivitas, Ukuran Perusahaan dan Penilaian Pasar terhadap Return Saham (Pada Perusahaan Real Estate dan Property di BEI) Periode Tahun 2009-2014, Journal of Accounting, 2 (2).

Nuryana,Ida, 2017., Pengaruh Tingkat Kesehatan Bank Terhadap Nilai Perusahaan Dengan Pofitabilitas Sebagai Variabel Intervening (Pada Bank Umum Swasta Nasional Periode 2011-2015., Seminar Nasional \& Call For Paper, FEB Unikama "Peningkatan Ketahanan Ekonomi Nasional Dalam Rangka Menghadapi Persaingan Global"Malang, 17 Mei, 613 - 631

Pandaya, J. Pujihastuti D dan Suprapta, I. (2020). Pengaruh Faktor Fundamental Terhadap Return Saham, Jurnal Akuntansi. 9 (2), 233 - 243.

Patricia, O. Hidayati, S. Wahyudi. (2021). Pengaruh Tingkat Kesehatan Bank terhadap Return Saham Perbankan di Indonesia. Konferensi Riset Nasional Ekonomi, Manajemen, dan Akuntansi (KORELASI). 2, 464 - 476.

Purnamasari, D. Nuraina, E dan Astuti, E. (2017). Pengaruh Capital Adequacy Ratio, Loan to Deposit Ratio dan Return on Asset terhadap Harga Saham Perusahaan Perbankan. Forum Ilmiah Pendidikan Akuntansi. 5 (1), 264-277.

Rahmani, N. A B. (2019). Pengaruh Return On Assets (ROA), Return On Equity (ROE), Net Profit Margin (NPM), Dan Gross Profit Margin (GPM) Terhadap Harga Saham Perbankan Syariah Periode Tahun 2014-2018. KITABAH: Volume 3. No. 2, $110-$ 120.

Sambul, S.H. Murni, S. Tumiwa, J. R. (2016). Pengaruh Kinerja Keuangan Perbankan terhadap Harga Saham yang Ditawarkan di Bursa Efek Indonesia (Studi Kasus 10 Bank dengan Aset Terbesar). Jurnal Berkala Ilmiah Efisiensi. 16 (02), 407 - 416. 
Srihayati D, Tandika, D. dan Azib. (2015). Pengaruh Kinerja Keuangan Perbankan terhadap Nilai Perusahaan dengan Metode Tobin'S, Proseding Penelitian SPeSIA, $43-49$.

Sulastiningsih dan Rizka I.S. (2018). Pengaruh Kinerja Keuangan dan Corporate Social Responsibility (CSR) terhadap Nilai Perusahaan Perbankan di Bursa Efek Indonesia., Jurnal Kajian Bisnis. 26 (1), 95 - 1114.

Sunardi, H. (2010). Pengaruh Penilaian Kinerja dengan ROI dan EVA terhadap Return Saham pada perushaan yang Tergabung dalam LQ 45 di Bursa Efek Indonesia. Jurnal Akuntansi, 2 (1), 70-92.

Sunaryo, D. (2020). Pengaruh Rasio Likuiditas, Aktivitas dan Profitabilitas terhadap Return Saham Sub Sektor Perbankkan BUMN di Bursa Efek Indonesia (BEI) Periode 2010-2018. Jurnal Manajemen Bisnis (JMB). 33 (2), 25-38.

Wahyuningsih, T dan Susetyo, A. (2020). Pengaruh ROE, TVA, dan DER Terhadap Return Saham pada Perusahaan Sub Sektor Perbankan dengan PBV sebagai Variabel Intervening., Jurnal Ilmiah Mahasiswa Manajemen, Bisnis dan Akuntansi. 2 (2), $228-239$.

Virolita, N, dan Yuliana, I. (2020). Pengaruh ROE terhadap Nilai Perusahaan dengan Struktur Modal Sebagai Variabel Moderating (Sub Sektor Makanan Minuman Tahun 2016-2018), Jurnal Ekonomi : Journal of Economic. 11 (1)., 82 - 87

Yudistira, E. R. dan Adiputra, I.M.P. (2020). Pengaruh Faktor Internal dan Ekternal Terhadap Harga Saham Jurnal Ilmiah Akuntansi dan Humanika. 10 (2), 176 - 184 